\title{
Animal Species and Evolution, by Ernst Mayr. Oxford University Press (for Harvard University Press), 70s. Ecological Genetics, by E. B. Ford. Methuen, $42 \mathrm{~s}$.
}

Ecology and genetics are the two biological time bombs of our age. Already the percipient can foresee the upheaval in our way of life which their discoveries will cause when the current fixation on nuclear physics and that other bomb gives way to a greater understanding of advances in biology. Both books are important aids in achieving this understanding; indeed both are among the books of the century in the field of evolution and genetics.

Dr. Mayr has produced the logical modern successor to Julian Huxley's Evolution : the Modern Synthesis, a complete survey of where Darwinism stands today in the Animal Kingdom. While not all that he says is noncontroversial-how could it be when his subject is one of the growth points of modern science? - the consensus of informed opinion would undoubtedly agree with the great bulk of it. When a consideration of animals alone has carried him to the length of 662 pages, it would be churlish to complain that he has not included plants, but one would still like to see the recent advances in this sphere integrated into the whole, as Dr. Ford does with his more limited field.

When a scientist as able as Edmund Brisco Ford puts his life work into a book it is well worth taking a little trouble to master it, even if the technicalities of genetics at first seem a little forbidding to the layman. Though he writes lucidly, Dr. Ford makes few concessions to those who do not know what a switch mechanism or a super-gene are, let alone a homozygote or an allele. But this book is so important that I strongly urge all naturalists to take the short course in elementary genetics which the author has provided in his two excellent New Naturalist volumes, Butterflies and Moths, and plunge into the fray.

Ecological genetics, in the author's own words, deals with the adjustments and adaptations of wild populations to their environment. It is thus of key importance to conservationists, who are seeking to achieve just this for the animals they wish to preserve, in an often vastly changed environment. The author is a real pioneer in taking genetics into the field instead of sitting in a laboratory counting fruit-flies, and much of the book consists of the interpretation of his own field work on butterflies and moths, especially the meadow brown in the Isles of Scilly and the scarlet tiger moth in Berkshire. Fundamental research of this sort in the field provides another lesson for conservationists : the urgent need to preserve intact the habitats of these key insect populations. Fortunately the wildlife of the Isles of Scilly is now being looked after by the Nature Conservancy, by a special arrangement, and a large part of the main Berkshire locality, Parsonage Moor at Cothill, has recently been leased for a nature reserve by the Berks, Bucks and Oxon Naturalists' Trust, and fenced with the aid of a grant from the World Wildlife Fund.

\section{R. S. R. FITTER}

\section{The Living World, by Rutherford Platt. Souvenir Press, 25s.}

It would be easy to be put off by the somewhat extravagant style of writing of this book. In the first few pages we are told that bees boil down nectar to make honey; that pollen is " a miracle drug which bees use to reproduce themselves"; and that pollination of plants by insects is "a reliable way to spark ovaries." But it is worth having patience. After 